University of Nebraska - Lincoln

DigitalCommons@University of Nebraska - Lincoln

U.S. Environmental Protection Agency Papers

U.S. Environmental Protection Agency

2008

Did State Regulation of Power Plants Cause an Increase in Pollution Exportation?

Allen S. Bellas

Metropolitan State University, 1501 Hennepin Ave., Minneapolis MN 55403-1897, USA

lan Large

Environmental Protection Agency

Follow this and additional works at: https://digitalcommons.unl.edu/usepapapers

Part of the Civil and Environmental Engineering Commons

Bellas, Allen S. and Large, lan, "Did State Regulation of Power Plants Cause an Increase in Pollution Exportation?" (2008). U.S. Environmental Protection Agency Papers. 1.

https://digitalcommons.unl.edu/usepapapers/1

This Article is brought to you for free and open access by the U.S. Environmental Protection Agency at DigitalCommons@University of Nebraska - Lincoln. It has been accepted for inclusion in U.S. Environmental Protection Agency Papers by an authorized administrator of DigitalCommons@University of Nebraska - Lincoln. 


\title{
Did state regulation of power plants cause an increase in pollution exportation? ${ }^{\text {t }}$
}

\author{
Allen S. Bellas ${ }^{\mathrm{a}, *}$, Ian Lange ${ }^{\mathrm{b}}$ \\ ${ }^{a}$ Metropolitan State University, 1501 Hennepin Ave., Minneapolis MN 55403-1897, USA \\ b Environmental Protection Agency, National Center for Environmental Economics, 1200 Pennsylvania Ave NW (1809T), \\ EPA West 4334G, Washington, DC 20008, USA
}

Received 3 June 2006; received in revised form 24 February 2007; accepted 27 April 2007

Available online 6 May 2007

\begin{abstract}
The 1970 Clean Air Act divided responsibility for achievement of air quality standards between the EPA and states. It is widely believed that, as a result, state-regulated sources received taller stacks, but analysis suggests that this is not true.
\end{abstract}

(C) 2007 Elsevier B.V. All rights reserved.

Keywords: Pollution; Clean Air Act; Stack heights; Coal

JEL classification: Q5; Q53; Q58

\section{Background}

\subsection{The division between federal and state}

The Clean Air Act Amendments (CAAA) of 1970 established National Ambient Air Quality Standards (NAAQSs) and assigned responsibility for achieving them. In particular, responsibility for stationary sources was divided between the federal government, through the Environmental Protection Agency

\footnotetext{
t3 The views expressed here are those of the authors and not necessarily those of the Environmental Protection Agency. The authors wish to thank David Simpson, David O'Hara, Evren Damar, and an anonymous referee for helpful suggestions.

* Corresponding author. Tel.: +1 612659 7272; fax: +1 6126597268.

E-mail address: allen.bellas@metrostate.edu (A.S. Bellas).
} 
(EPA), and the states. The EPA was authorized to establish uniform emissions standards for new sources called new source performance standards (NSPS) while states were given the responsibility for controlling emissions from existing sources to achieve compliance with NAAQSs (Portney, 2000).

States, under pressure to meet NAAQS, would likely seek low cost means of doing so. One inexpensive option for reducing ambient pollution levels is to dilute/export pollution through increased stack heights. ${ }^{1}$ Taller smokestacks can improve local air quality without reducing total emissions. Prior to dissemination of information about control options (scrubbing, etc.) and the possible regional or global effects of emissions, it was believed that local air quality problems could be effectively addressed through taller stacks. Even if there was knowledge of pollution-removing devices, there were clear cost advantages to building up. Ackerman and Hassler (1981) estimate that in 1975, the cost of building a tall smokestack was $3 \%$ to $17 \%$ of the cost of popular pollution control equipment. As such, it would not be surprising if stack heights increased as a result of the CAAA.

\subsection{The widely believed effect of state versus federal regulation}

It is widely believed that one effect of the CAAA's division of responsibility between states and the federal government was that states offered the electric generation plants they regulated incentives to build taller smokestacks. This is particularly true for coal-fired boilers that tend to produce relatively high levels of four NAAQS pollutants. The goal of encouraging taller stacks was to send emissions high into the atmosphere to be more widely dispersed, perhaps beyond the state's borders, improving the emitting state's air quality. Federally regulated boilers, on the other hand, faced no such incentives, as federal regulators would find no advantage in interstate transport of emissions. The widely believed end result is that state-regulated boilers received taller stacks than did federally regulated boilers; specifically due to the incentives of the NAAQS. While examples of this belief are common, including Tietenberg (2004), Kahn (2005) and Ellerman et al. (2000), no previous empirical evidence has been presented. This paper presents empirical results testing the proposition that state-regulated boilers had taller stacks built for them than did federally regulated boilers.

\subsection{History and rules about stacks and exporting pollution}

This paper investigates the relationship between environmental regulation and stack heights, but this requires some explanation of the relevant regulations.

Environmental regulations are generally applied to boilers within plants. Stacks are associated with a particular type of regulation only through their associated boiler or boilers. Boilers built before 1971 are subject to relatively lax state regulation and present opportunities for reduction of local pollution concentrations through the construction of newer, taller stacks. Boilers built after 1971 are subject to strict federal regulation. The federal government should be less inclined to push stacks higher to improve local air quality if the pollution will simply wind up somewhere else.

\footnotetext{
1 “... a stack is defined as a tall, vertical structure containing one or more flues used to discharge products of combustion to the atmosphere.... a flue is defined as an enclosed passageway within a stack for directing products of combustion to the atmosphere." EIA (2002), p. iii.
} 
A U.S. Court of Appeals ruling in 1983 restricted the use of tall stacks to meet pollution regulations (UPI, 1983). ${ }^{2}$ This is somewhat surprising in that the federal government reviewed state implementation plans and would seem likely to reject those depending on increased stack heights and export of emissions. In addition, Section 110 of the CAAA of 1970 (EPA, 1970) actually contains language that would seem to deter or prevent large-scale exportation of pollution. However, Portney (2000) and the National Commission on Air Quality (1981) suggest that in practice this language has proven inadequate. Part of the reason for this inadequacy may be related to language in the Act restricting a locality's ability to call for an interstate conference to resolve transboundary pollution problems if an ambient air quality standard exists for that pollutant, as is the case for most power plant emissions. Section 123 of the current version of the CAAA (EPA, 1990) addresses stack heights to some extent, saying:

"The degree of emission limitation required for control of any air pollutant... shall not be affected in any manner by so much of the stack height of any source as exceeds good engineering practice... or any other dispersion technique."

According to the Buonicore and Davis (1992), good engineering practice for a stack height is equal to 2.5 times the height of the nearest building. This language is echoed in numerous state pollution plans. However, Section 123 goes on to say, "In no event may the Administrator prohibit any increase in any stack height or restrict in any manner the stack height of any source."

Our goal is to test whether states intended to comply with the CAAA by exporting their emissions through taller stacks at units they regulated. The expectation is that from 1971 to the mid-1980s stacks built for state-regulated boilers will be taller than those built for federally regulated boilers. To be clear, it is the difference in regulation that might drive the difference in stack heights. This analysis will be conducted for boilers fueled by coal and for two cleaner fuels, petroleum and gas, for comparison.

\section{Data}

Data are taken from the Energy Information Administration's Form 767 from 1996, which collects information on design, operation and regulation of boilers, stacks and pollution control units at U.S. steam-electric plants (EIA, 1996, 2002).

Graphical analysis of mean stack heights, presented in Fig. 1, suggests that new stacks increased in height from the 1950s to the 1980s. The data include the dates that both the boiler and stack came on line and the type of regulation to which the boiler is subject. The unit of analysis is the stack itself rather than the associated boiler and the dependent variable is the stack height in feet. The explanatory variables are: a state regulation dummy, the stack's in-service year, the capacity of the boiler (in thousand pounds of steam per hour), the stack exit velocity ${ }^{3}$, a dummy variable indicating whether the unit was subject to local $\mathrm{SO}_{2}$ standards that were more stringent than federal or state standards, a dummy variable indicating the plant is located in a county that borders another state, a dummy variable indicating the plant is located in a metropolitan statistical area (MSA), dummy variables indicating the presence of a flue gas desulfurization (FGD) pollution control unit, a flue gas particulate (FGP) control unit and equipment for reduction of nitrogen oxide $\left(\mathrm{NO}_{x}\right)$ emissions, the sulfur $\left(\mathrm{SO}_{2}\right)$ emissions limit to which the plant was subject and regional dummy variables. Summary statistics are presented in Table 1.

\footnotetext{
2 “Agency Must Rethink Rules on Smokestacks", New York Times, October 12, 1983.

3 Plants can have a higher "effective stack height" if the emissions leave the stack at a higher velocity.
} 


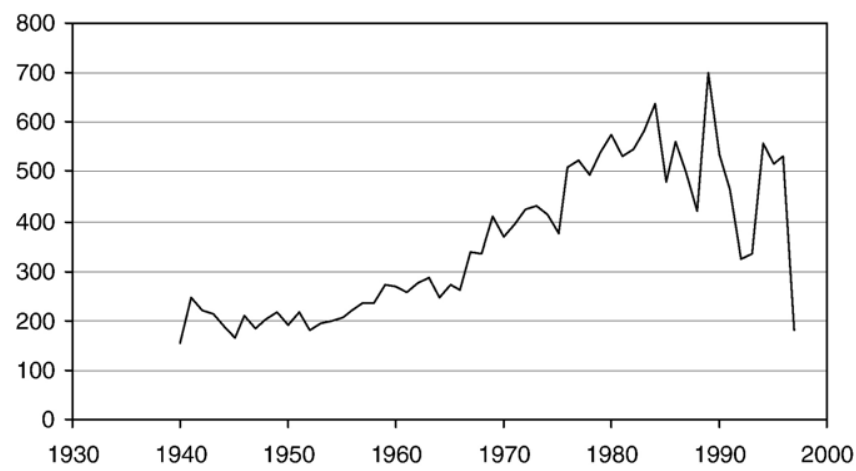

Fig. 1. Mean height of new stacks by year, in feet.

If states were using tall stacks to export pollution then the state regulation and border county dummy should have a positive effect on stack height. The presence of any type of pollution control equipment or strict local regulation or a strict $\mathrm{SO}_{2}$ emissions limit should be associated with shorter stacks, as they would result in cleaner emissions that need not be exported.

\section{Analysis and results}

The analysis presented here is based on observations from the years 1971 through 1986. The cut-off of 1986 is chosen as this is when construction of new plants and/or stacks slowed considerably and it

Table 1

Summary statistics, 1971-1986

\begin{tabular}{|c|c|c|c|c|c|c|c|c|}
\hline \multirow{3}{*}{$n$} & \multicolumn{2}{|c|}{ All stacks } & \multicolumn{2}{|c|}{ Gas stacks } & \multicolumn{2}{|c|}{ Petrol stacks } & \multicolumn{2}{|c|}{ Coal stacks } \\
\hline & \multicolumn{2}{|l|}{481} & \multicolumn{2}{|l|}{92} & \multicolumn{2}{|l|}{47} & \multicolumn{2}{|l|}{342} \\
\hline & Mean & S.D. & Mean & S.D. & Mean & S.D. & Mean & S.D. \\
\hline Height (ft) & 484.16 & 230.59 & 203.40 & 96.63 & 412.57 & 151.71 & 569.53 & 199.92 \\
\hline State & 0.57 & 0.50 & 0.79 & 0.41 & 0.79 & 0.41 & 0.49 & 0.50 \\
\hline Stack year & 1976.90 & 4.11 & 1973.91 & 2.33 & 1974.98 & 2.78 & 1977.97 & 4.15 \\
\hline Capacity & 4215.36 & 3766.76 & 2606.27 & 2092.95 & 4457.43 & 3421.82 & 4614.95 & 4044.36 \\
\hline Velocity & 80.23 & 28.11 & 69.26 & 35.81 & 80.96 & 26.28 & 82.95 & 25.38 \\
\hline Local & 0.03 & 0.16 & 0.05 & 0.22 & 0.04 & 0.20 & 0.02 & 0.14 \\
\hline FGD & 0.21 & 0.40 & & & & & 0.29 & 0.45 \\
\hline FGP & 0.78 & 0.41 & 0.07 & 0.25 & 0.62 & 0.49 & 1.00 & 0.00 \\
\hline $\mathrm{NO}_{x}$ & 0.24 & 0.43 & 0.07 & 0.25 & 0.02 & 0.15 & 0.32 & 0.47 \\
\hline $\mathrm{SO}_{2}$ & 3.96 & 4.05 & & & & & 3.97 & 4.06 \\
\hline Border & 0.49 & 0.50 & 0.33 & 0.47 & 0.79 & 0.41 & 0.50 & 0.50 \\
\hline MSA & 0.50 & 0.50 & 0.67 & 0.47 & 0.94 & 0.25 & 0.39 & 0.49 \\
\hline West & 0.46 & 0.50 & 0.78 & 0.41 & 0.09 & 0.28 & 0.42 & 0.49 \\
\hline Northeast & 0.10 & 0.30 & 0.01 & 0.10 & 0.62 & 0.49 & 0.05 & 0.22 \\
\hline Southeast & 0.20 & 0.40 & 0.16 & 0.37 & 0.23 & 0.43 & 0.21 & 0.41 \\
\hline Midwest & 0.24 & 0.43 & 0.04 & 0.21 & 0.06 & 0.25 & 0.32 & 0.47 \\
\hline
\end{tabular}


Table 2

Regression results by fuel type, 1971-86

Dependent variable: stack height

\begin{tabular}{|c|c|c|c|c|}
\hline & (1) & (2) & (3) & (4) \\
\hline & Gas & Oil & Coal & Coal \\
\hline State & $\begin{array}{l}-22.62 \\
(22.05)\end{array}$ & $\begin{array}{l}-75.68 \\
(81.94)\end{array}$ & $\begin{array}{l}43.24 \\
(33.36)\end{array}$ & $\begin{array}{l}150.07 \\
(48.07)^{* * *}\end{array}$ \\
\hline Year & $\begin{array}{l}11.46 \\
(3.96)^{* *}\end{array}$ & $\begin{array}{l}9.31 \\
(12.96)\end{array}$ & $\begin{array}{l}1.78 \\
(3.51)\end{array}$ & $\begin{array}{l}1.54 \\
(3.46)\end{array}$ \\
\hline Capacity & $\begin{array}{l}0.023 \\
(0.004)^{* * *}\end{array}$ & $\begin{array}{l}0.018 \\
(0.007)^{* *}\end{array}$ & $\begin{array}{l}0.013 \\
(0.003)^{* * *}\end{array}$ & $\begin{array}{l}0.035 \\
(0.008)^{* * *}\end{array}$ \\
\hline State $\times$ capacity & & & & $\begin{array}{l}-0.025 \\
(0.008)^{* * *}\end{array}$ \\
\hline Velocity & $\begin{array}{l}0.19 \\
(0.25)\end{array}$ & $\begin{array}{l}0.10 \\
(1.22)\end{array}$ & $\begin{array}{l}0.71 \\
(0.44)\end{array}$ & $\begin{array}{l}0.75 \\
(0.43)^{*}\end{array}$ \\
\hline Local & $\begin{array}{l}79.18 \\
(34.40)^{* *}\end{array}$ & $\begin{array}{l}-100.67 \\
(129.02)\end{array}$ & $\begin{array}{l}-111.08 \\
(89.86)\end{array}$ & $\begin{array}{l}-100.47 \\
(88.42)\end{array}$ \\
\hline FGD & & & $\begin{array}{l}20.42 \\
(31.20)\end{array}$ & $\begin{array}{l}23.36 \\
(30.70)\end{array}$ \\
\hline FGP & $\begin{array}{l}43.37 \\
(33.93)^{*}\end{array}$ & $\begin{array}{l}43.49 \\
(48.90)\end{array}$ & & \\
\hline $\mathrm{NO}_{x}$ & $\begin{array}{l}-15.25 \\
(34.82)\end{array}$ & $\begin{array}{l}-72.31 \\
(148.76)\end{array}$ & $\begin{array}{l}-4.73 \\
(28.61)\end{array}$ & $\begin{array}{l}-4.15 \\
(28.14)\end{array}$ \\
\hline $\mathrm{SO}_{2}$ & & & $\begin{array}{l}-2.16 \\
(2.87)\end{array}$ & $\begin{array}{l}-1.87 \\
(2.82)\end{array}$ \\
\hline Border & $\begin{array}{l}11.82 \\
(18.03)\end{array}$ & $\begin{array}{l}57.33 \\
(59.71)\end{array}$ & $\begin{array}{l}33.17 \\
(22.79)\end{array}$ & $\begin{array}{l}30.86 \\
(22.42)\end{array}$ \\
\hline MSA & $\begin{array}{l}-35.23 \\
(17.18)^{* *}\end{array}$ & $\begin{array}{l}152.89 \\
(87.42)^{*}\end{array}$ & $\begin{array}{l}-65.66 \\
(24.05)^{* * *}\end{array}$ & $\begin{array}{l}-63.28 \\
(23.66)^{* * *}\end{array}$ \\
\hline West & $\begin{array}{l}-141.56 \\
(80.59)^{*}\end{array}$ & $\begin{array}{l}-59.47 \\
(95.81)\end{array}$ & $\begin{array}{l}-196.80 \\
(56.27)^{* * *}\end{array}$ & $\begin{array}{l}-180.70 \\
(56.50)^{* * *}\end{array}$ \\
\hline Southeast & $\begin{array}{l}-69.85 \\
(85.53)\end{array}$ & $\begin{array}{l}-37.65 \\
(56.23)\end{array}$ & $\begin{array}{l}47.54 \\
(57.95)\end{array}$ & $\begin{array}{l}54.36 \\
(57.01)\end{array}$ \\
\hline Midwest & $\begin{array}{l}-151.83 \\
(85.16)^{*}\end{array}$ & $\begin{array}{l}-75.01 \\
(97.37)\end{array}$ & $\begin{array}{l}-113.53 \\
(56.32)^{* *}\end{array}$ & $\begin{array}{l}-98.00 \\
(55.61)^{*}\end{array}$ \\
\hline Constant & $\begin{array}{l}252.92 \\
(94.94)^{* *}\end{array}$ & $\begin{array}{l}144.61 \\
(190.28)\end{array}$ & $\begin{array}{l}549.52 \\
(79.11)^{* * *}\end{array}$ & $\begin{array}{l}439.46 \\
(85.79)^{* * *}\end{array}$ \\
\hline Observations & 86 & 47 & 252 & 252 \\
\hline$R$-squared & 0.58 & 0.46 & 0.36 & 0.39 \\
\hline
\end{tabular}

Standard errors in parentheses. * significant at $10 \% ; * *$ significant at $5 \% ; * *$ significant at $1 \%$.

provides for a lag in the U.S. Appeals court decision discussed above. The analysis was performed for three types of fuel, listed in order of their emissions potential: coal, oil, and natural gas. The following linear regression model was estimated.

Height $_{i}=\beta_{0}+\beta_{1}$ State $_{i}+\beta_{2}$ Year $_{i}+\beta_{3}$ Capacity $_{i}+\beta_{4}$ Velocity $_{i}+\beta_{5}$ Local $+\beta_{6}$ FGD $_{i}$ $+\beta_{7} \mathrm{FGP}_{i}+\beta_{8} \mathrm{NO}_{i}+\beta_{9}$ Sulfur $_{i}+\beta_{10}$ Border $+\beta_{11}$ MSA $+\beta_{12}$ Region $+\varepsilon_{i}$ 
where Height ${ }_{i}$ is the height of stack $i$ in feet, the explanatory variables are as described above and $\varepsilon_{i}$ is a stochastic error term ${ }^{4}$. A second specification adds a cross term relating state regulation and capacity for coal-fired boilers.

The results, presented in Table 2, suggest that state-regulated stacks were not significantly taller than federally regulated stacks. The positive (though insignificant for coal and oil) coefficients on year are consistent with a gradual upward trend in stack heights. Total capacity of the associated boiler had a positive and significant effect on stack height, suggesting that larger boilers had taller stacks built for them. Estimated coefficients on the regional dummies suggest that stacks in the northeast (the excluded category in this analysis) are consistently taller than stacks elsewhere in the country.

Looking solely at coal-fired power plants, there is no statistically significant height difference between state-regulated and federally regulated units. Stacks located in MSAs were statistically significantly shorter by about $10 \%$. The estimated coefficients on emissions control variables (FGD, FGP, $\mathrm{NO}_{x}$, and $\mathrm{SO}_{2}$ emissions limits) were statistically insignificant. ${ }^{5}$ These results imply variables that reduce the incentive to build a tall stack, have no significant impact on stack height. These results suggest that states were not able to export pollution through tall stack heights.

When the interaction term relating state regulation and capacity is added to the model for coal-fired boilers, the results change. The estimated coefficient on the state regulation dummy becomes positive and significant, but this is offset by the negative coefficient on the interaction term. This means that for a coalfired boiler of median capacity, a state-regulated stack is predicted to be $54.5 \mathrm{ft}$, or about $10 \%$, taller than a federally regulated stack. These results are surprising because larger boilers, with potentially greater emissions, have shorter predicted stack heights if state-regulated than they would have if federally regulated. This suggests that states did not have the ability to differentially push stacks higher to export emissions, even among the dirtiest units that they regulated.

\section{Discussion}

It is widely believed that in the 1970s, states responded to the air quality standards imposed by the CAAA by encouraging the construction of taller stacks at the coal-fired plants they regulated. The goal of this policy was to either disperse or transport pollutants from relatively dirty coal-fired plants and achieve improvements in state air quality at the lowest possible cost. However, the results presented here are inconsistent with this story. We find that the level of government at which a boiler was regulated had no significant impact on the height of a new stack built for it during this period and that states seem to have been incapable of forcing stacks higher to export emissions.

As we move into an era of several new attempts to deal with air quality issues (Clean Air Interstate Rule, Mercury Rule) by transferring authority to states, these results are instructive. It seems that concerns about states addressing air quality issues by transporting emissions elsewhere are not strongly supported by the data for the period we examine. States' ability to export emissions may have been checked by EPA regulators whose focus was more regional than conventional wisdom suggests or by the fact that the EPA had to approve state pollution plans. If these results can be generalized, a localized approach to pollution regulation may not carry with it the problem of intentional interstate export of emissions and air quality

\footnotetext{
${ }^{4}$ Only coal-fired boilers had an FGD device or an $\mathrm{SO}_{2}$ emissions limit.

5 Attempts to identify a differential effect of FGD units on heights of state and federally regulated stacks yielded no significant difference. Results available on request.
} 
problems. While interstate transport of emissions is certainly a potential problem, at least in the case of the early years of the CAAA, states don't seem to have intentionally made the problem worse in an attempt to clean their own air. If states were unable to freely export pollution in the early years of the CAAA, it seems unlikely that they will be able to in the future given our greater understanding of pollution transportation.

\section{References}

Ackerman, Bruce, Hassler, William, 1981. Clean Coal/Dirty Air. Yale University Press, New Haven CT.

Buonicore, Anthony, Davis, Wayne (Eds.), 1992. Air Pollution Engineering Manual, Air \& Waste Management Association. Van Nostrand Reinhold, New York, NY.

Ellerman, A., Denny, Richard Schmalensee, Bailey, Elizabeth M., Joskow, Paul L., Montero, Juan-Pablo, 2000. Markets for Clean Air: The U.S. Acid Rain Program. Cambridge University Press, Cambridge U.K.

Energy Information Administration, 1996. Form EIA-767: Steam Electric Plant Operation and Design Report (Washington D.C.). Energy Information Administration, 2002. Form EIA-767: Steam Electric Plant Operation and Design Report (Washington D.C.). Environmental Protection Agency, 1970. The Clean Air Act (Washington, D.C.).

Environmental Protection Agency, 1990. The Clean Air Act (Washington, D.C.).

Kahn, James R., 2005. The Economic Approach to Environmental \& Natural Resources, 3rd edition. Thomson South-Western, U.S.A.

National Commission on Air Quality, Report to Congress, 1981. To Breathe Clean Air. Washington, D.C.

Portney, Paul R., 2000. Air Pollution Policy. In: Portney, Paul, Stavins, Robert (Eds.), Public Policies for Environmental Protection. Resources for the Future, Washington D.C.

Tietenberg, Tom, 2004. Environmental Economics \& Policy, 4th edition. Pearson Addison Wesley, Boston, MA.

UPI, 1983. Agency Must Rethink Rules on Smokestacks. New York Times, p. A17. October 12. 